\title{
Weather Manifested Rice Cultivation - A Review
}

\author{
Athar Nishat Islam ${ }^{1 *}$, Punya Gogoi Khanikar ${ }^{1}$, Rajib Lochan Deka ${ }^{1}$, \\ Bikashjyoti Gharphalia ${ }^{1}$, Pranjal Dutta ${ }^{1}$ and Kuldip Medhi ${ }^{2}$
}

${ }^{1}$ Department of Agrometeorology, Assam Agricultural University, Jorhat-13, India

${ }^{2}$ Regional Agricultural Research Station, AAU, Gossaigaon, India

*Corresponding author

\begin{tabular}{|l|}
\hline Ke y w o r d s \\
Rice, Productivity, \\
Meteorological \\
elements
\end{tabular}

\section{Keywords}

Rice, Productivity, Meteorological elements

ctober 2018

\section{A B S T R A C T}

Under the scenario of an escalating population and an epoch of climate variability, increasing the production of rice to confront the food security and overcome the human demands from the ever shrinking land resources have emerged as an obligatory step in augmenting the nations' economy. Rice productivity system is subjected to wide aberrations in the economic output and identifying the impact of weather variation at different phonological events of the crop is the predominant area of concern as it may help in understanding their response in terms of final productivity and enhance the functioning of the yield predicting models. Such assessment would enable not only to understand the extent of changes in rice production which could be already occurring due to changes in historical climate, but also to identify the rice producing regions vulnerable to weather shocks. Confiscating the biotic events and other abiotic factors, meteorological elements precisely, rainfall and temperature were identified as the paramount factors invariably controlling the potential grain yield of the crop. Rise in atmospheric temperature is detrimental for Asian rice as it may affect the phenology and physiology of the crop, and thereby, causing spikelet sterility, disruption of plant respiration, photosynthesis and shortening of grain-filling period, all of which leads to lower productivity. Further, extreme rainfall events during sowing and transplanting in high water table regions as well as deficit of the same at time of emergence and reproductive stage can diminish productivity.

\section{Introduction}

Rice is unique among the major cereals by virtue of its extent and adaptability to wider range of edaphic, climatic and cultural conditions. Though it is a hydrophilic in nature and often cultivated as a semi aquatic crop, there are varieties and strains which are grown under dry or rainfed and semi dry condition. Weather determines the potential production of rice varieties and these affects are manifested through plant characteristics like height, tillers, leaf area and number of panicle that ultimately determines the final grain yield. Significant changes have occurred in the climate of the tropical region during the $20^{\text {th }}$ century (Ramanathan et al., 2001; Ramanathan et al., 2005; Kumari et al., 2007) and that in some regions of the tropics, weather is already approaching critical levels 
during the susceptible stages of rice growth (Wassmann et al., 2009a). Under changing climatic scenario, extreme meteorological events are predicted and these changes will most likely make the stress even more common and severe in addition to the ongoing stresses of yield stagnation, land-use by the non-agricultural sector, competition for land, water and other resources. The observed climatic changes and attributed weather fluctuations in the past may have had significant influences on rice productivity in the tropics and thus, assessing the historical weather sensitivity of rice in this region is important (Wassmann and Dobermann, 2007). Such assessment would enable to not only understand the extent of changes in rice production which could be already occurring due to changes in historical climate, but also to identify the rice producing regions vulnerable to weather shocks. Hence, the present study has been undertaken primarily to review the impact of temperature and rainfall on the yield attributes of rice and their relative influence during various crop phenophases including the critical stages of growth.

\section{Impact of weather parameters on rice production}

Crops grow to their best under a range of abiotic factors and any deviation from optimum range will lead to aberrant changes in physiological processes and they may experience severe stress (Orcut and Nilsen, 2000). Production and productivity of rice in terms of its yield, grain weight and number of grains per unit area vary in response to agrometeorological parameters that accelerate the processes of plant growth such as crop transpiration, photosynthesis and photothermal efficiency (Mall and Singh, 2000). Moreover, meteorological parameters vary yearly and intra and inter-seasonal variations play a pivotal role in determining the final crop yield (Prabhjyot and Hundal, 2009). Under unlimited water supply, the most important weather parameters affecting growth and development of rice are temperature and solar radiation (Sridevi and Chellamuthu, 2015). The impact of other weather parameters such as relative humidity and wind velocity are not considered so crucial. Further, reproductive and ripening phases are the most sensitive to weather, and in order to obtain the potential yield of the crop, adjustment must be done in the cropping schedule to reduce the risk of unfavorable weather condition during these stages. On the other hand Gorski et al., (1994) and Gorski and Gorska (2003) reported that weather variability at the sowing/planting and reproductive (ripening) phase is equally important that contribute more towards grain size and crop yield. Shahid et al., (2013) investigated the effect of inter-seasonal variations in meteorological parameters on morphological and yield traits of autotetraploid and diploid rice including indica and japonica genotypes and concluded that photothermal quotient showed closer relationship with yield and seed set compared to temperature or solar radiation alone. The impact of the individual weather events vary with the advancement in the phenological age of a crop and it is a fundamental step to perceive an elaborate knowledge of the influence of different weather parameters on the final yield of rice.

\section{Impact of temperature}

Temperature is considered to be the most critical yield determinant of rice and high temperature in the lower elevation of the tropics and lower temperature in the temperate regions adversely affect the crop (Yoshida, 1981). Moderate warming in the coming decades, will possibly imply a net negative impact on yield of rice (Welch et al., 2010) and the productivity may decrease by 
4.17\% (Upadhyay, 2012). All-India kharif rice yield would have been 8.4 per cent higher (or cumulative 172 million tons) had the pre1960 climate prevailed during 1969-2007 (Pattanayak and Kumar, 2013). The critical limits of the weather parameters required for growth and development of the crop have already reached its threshold in most parts of the globe and any further increase of temperature in the future, as predicted by the IPCC (2013) will drastically reduce its grain yield (Wassmann et al., 2009a). The rise in atmospheric temperature causes detrimental effects on growth, yield, and quality of the rice crop by affecting its phenology, physiology, and yield components (Singh, 2001 and Sheehy et al., 2005). It can affect the crop at all stages of development, particularly during flowering when it causes spikelet sterility. It increases plant respiration, affects photosynthesis and shortens the grainfilling period, all of which leads to lower productivity (Peng et al., 2004). On the other hand, relatively low temperature and high solar radiation during the reproductive stage had remarkable effects on increasing spikelet number and hence grain yield (Yoshida and Parao, 1976). Rise in the night temperature is another reason for decline in historical rice yield in addition to the observed changes in the climatic conditions (Kumar, 2004) particularly during the ripening phase of the crop (Auffhammer et al., 2012). Night-time warming at the end of the growing season had a greater impact on yield than the increase in the maximum temperature and changes in rainfall characteristics (Auffhammer et al., 2011; Auffhammer et al., 2006). Due to increase in minimum temperature along with decrease in radiation, the potential yield trend of rice from 1985 to 2000 were found to be negative at six of the nine sites of India, four of which were statistically significant (Pathak et al., 2003). Increase in both frequency and intensity of high temperature, along with its large variability, is emerging as a potential threat to the sustainability of rice production as it is a $\mathrm{C}_{3}$ plant and in such plants growing under hot tropical conditions photosynthesis becomes inefficient when the temperature rises above long term mean temperatures and deteriorates further when temperature increases beyond this threshold, which is likely to be the cause due to global warming (Jagdish et al., 2007). High temperature stimulates grain filling rate and shortens grain filling period to increase protein content and chalky grains but decrease amylase and grain weight as well as reduce pollen germination percentage and cause sterility of spikelet which ultimately reduces grain yield (Kim et al., 2011). Such reduction in grain size and amylase content further reduces the potential economic benefits farmers can derive due to depression in farm-gate and/or milled grain prices (Zhu et al., 2005 and Yamakawa et al., 2007).

Yoshida (1973) from IRRI, Philippines reported that the seedling growth is very sensitive to temperature in the first week of post-germination. The growth rate increases linearly between 22 and $31^{\circ} \mathrm{C}$, suggesting that chemical reactions dominate growth. The enzymatic breakdown of the seed reserves support more than 70 per cent of growth during this week. After the first week, temperature influences on growth is less and the relative growth rates are about the same at $25{ }^{\circ} \mathrm{C}, 28{ }^{\circ} \mathrm{C}$, and $31{ }^{\circ} \mathrm{C}$. During the tillering stage, increase in the temperature resulted in an increased number of tillers per plant. At 35 weeks after sowing, temperature only slightly affected the tillering rate and the relative growth rate, except at the lowest temperature $\left(22^{\circ} \mathrm{C}\right)$ tested. Yoshida (1981) explained the cardinal range of temperature required for optimum growth and development of rice according to its phenological phases and suggested that the minimum, optimum and maximum cardinal range of temperature for the rice crop at 
germination stage is $10{ }^{\circ} \mathrm{C}, 20-25^{\circ} \mathrm{C}$ and $45^{\circ} \mathrm{C}$ respectively; at tillering stage it is $9-16^{\circ} \mathrm{C}, 25$ $31{ }^{\circ} \mathrm{C}$, and $33{ }^{\circ} \mathrm{C}$ respectively; at anthesis it is $22{ }^{\circ} \mathrm{C}, 30-33{ }^{\circ} \mathrm{C}$ and $35{ }^{\circ} \mathrm{C}$ respectively; at ripening it is $12-18{ }^{\circ} \mathrm{C}, 20-25{ }^{\circ} \mathrm{C}$ and $30{ }^{\circ} \mathrm{C}$ respectively. At panicle initiation stage the lower threshold limit should not exceed $15^{\circ} \mathrm{C}$. At some stations in India, the maximum rice yield was observed when maximum and minimum temperatures ranged between 29-32 $\mathrm{C}$ and 23-25 $\mathrm{C}$ respectively (Samui, 1999). In Punjab rice grain yield was positively correlated with maximum temperature during the entire growth period and the deviation of maximum temperature from normal in high yield years was less compared to that in the low yield years (Sandhu et al., 2013) from) and such results were in consonance with the findings of Islam et al., (2017). Grain yields reached the plateau at mean daily minimum air temperature of $23^{\circ} \mathrm{C}$, mean daily mean air temperature of $26.5{ }^{\circ} \mathrm{C}$ and mean daily maximum air temperature of $29{ }^{\circ} \mathrm{C}$ (Ho et al., 2013).

Higher temperatures can adversely affect Asian rice yields through two principal pathways, viz., higher maximum temperatures in combination with high humidity causing spikelet sterility and adversely affect grain quality and increased night time temperatures that may reduce assimilate accumulation (Wassmann et al., 2009b). Oh-e et al., (2007) investigated the effect of temperature variation on rice in a temperature gradient chamber study in Japan and found that crops exposed to 3.6 and $7.0{ }^{\circ} \mathrm{C}$ higher temperature than ambient, from heading to middle ripening stage, reduced photosynthesis by 11.2 to 35.6 per cent, respectively. This decline in the photosynthesis can be attributed to structural changes in the organization of thylakoids (Karim et al., 1997) and more particularly due to loss of stacking of grana in the chloroplast or its ability to swell (Wahid et al., 2007). In consonance to such results
Rani and Maragatham (2013) also summarized that, under elevated temperature of $4^{\circ} \mathrm{C}$ and $2^{\circ} \mathrm{C}$, the grain yield was 23 and 13.3 per cent less from the ambient. It was suggested that yield loss under elevated temperature is most possibly due to anomaly in temperature which affected the cellular developmental processes leading to reduced fertility, grain quality (Barnabas et al., 2008) in addition to higher grain dry matter accumulation rate leading to shortened grainfilling period (Kobata and Uemuki, 2004). Chen et al., (2014) provided a county-level analysis of the impacts of weather variability on rice yield in China, and found that temperature had statistically significant impacts on rice yield during the vegetative and ripening stages. In contrast to nearly all previous studies focusing on rice production in tropical and subtropical regions, they discovered that higher daily minimum temperature during the vegetative stage increased rice yield in China. Consistent with other studies, higher daily maximum temperature during the vegetative and ripening stages reduced rice yield in China. Various models developed to study the effects of weather variables on rice yield in India at different stages of growth indicated that above average maximum daily temperature had beneficial effects during ripening stage, detrimental effects during reproductive stage of the crop, while, in the initial growth and lag vegetative phase effects were fluctuating. The effect of increase in minimum temperature was beneficial during initial lag vegetative and reproductive stages, detrimental during ripening stages, and fluctuating during active reproductive stage (Agarwal et al., 1984).

\section{Impact of rainfall}

Rainfall variability has significant impact on the agricultural productivity system and when the annual rainfall diverges from its mean, the 
yield levels of all the agricultural crops diminish significantly (Aberra, 2011). Rice crop is very much sensitive to weather conditions, with high water requirement per unit of produced mass (Heinemann and Stone, 2009). The effect of rainfall variation on rice production changes over time and such nonstationarity can be explained by long-term rainfall change. However, the mechanism causing this change remains unclear, and there are still many uncertainties in the nonstationarity of the rainfall-rice production relationship (Asada and Matsumoto, 2009). Economic output of rainfed rice is in consonance with fluctuating total amount of rainfall, total number of rainy days and period of monsoon season, and yields are significantly correlated with the quantum of rainfall, length of rainy season and number of rainy days (Gupta et al., 2000). Global studies suggests that rice harvest have declined over the period 1972-1998 due to the changes in historical climate characteristics attributable to the combined influence of atmospheric brown clouds and greenhouse gas emissions causing variability in rainfall, solar radiation and other economic variables (Auffhammer $e t$ al., 2006). Simulation studies confirmed that much increase in rainfall and mean temperature in long run will negatively affect rice production in future (Shakoor et al., 2015). Further, drought stress, generally caused by scarcity in precipitation, is severely damaging during reproductive stages of the crop, especially during flowering, although drought in other stages can also lead to significant yield reductions (Liu et al., 2006).

The rice crop reacts differently to climatic variables during different stages of its growth and an increase particularly in rainfall seems beneficial throughout the crop season suggesting that crop production can be increased by supplying additional water (Agarwal et al., 1979). The effect of total rainfall was found beneficial during the vegetative phase of the crop (Hoa and Singh, 1993) with significant correlations (Bhargava, 1974), whereas, the number of rainy days during the same phase was negatively correlated with the grain yield (Reddy and Reddy, 1992 and Ogbuene, 2010). Low rice yields coincided with years of deficient or poorly distributed rainfall, and thus, excess water should be collected in high rainfall months in run-off ponds for the use for use at critical growth stages (Chaudhary, 1998). Ekanayake et al., (1993) from Virginia investigated the nature of panicle resistance to water loss by understanding the effect of low tissue water potentials and relative water content (RWC), induced by water deficit stresses, on diffusive resistance, transpiration rate and degree of tissue desiccation. They revealed that, increased water losses during the flowering stage causes spikelet sterility, white heads and yield losses, particularly in upland areas. Girish and Hittalmani (2004) found that moisture stress after 10 days of 50 per cent flowering significantly reduced single panicle weight, test weight, fertile spikelets per panicle, total spikelets per panicle and spikelet density and significantly increased sterile spikelets per panicle. 10 days after 50 per cent flowering is the most critical stage for grain filling and that, panicle initiation stage is more sensitive to moisture stress. Water deficit, even if moderate, can cause high-yield losses, especially when occurring during flowering and early grain filling and may be one of the major reasons for considering upland rice crops under high climate risk (Silva and Assad, 2001). Further, continuous cloudy days or rainfall during critical stages of growth, such as panicle differentiation or grain-filling stages, often induce great loss of grain yield and poor grain quality (Praba et al., 2004). The growing season rainfall intensity (GRSI) on rice yield variability was found significantly negative $(\mathrm{p}<0.1)$ which indicated that, an increase in rainfall intensity would result in a decreased 
variability of rice yield and thus, production risk in rice farming was reduced as rainfall intensity increased (Edeh et al., 2011). This collaborates the finding of Adams et al., (2000) and Chen et al., (2000) that increase in rainfall results in decreased variability of crop yield. Hence, the growing rainfall intensity is a risk-reducing environmental factor in rice production. Moreover, the growing season rainfall duration (GSRD) had its coefficient negatively signed though not significant with the final yield of the crop. Asada et al., (2009) studied the regional differences in the temporal variation of the correlation coefficient between rainfall and yield and observed that the correlation coefficient in Uttar Pradesh (UP) of India remained high, and exceeded the 5\% significance level. In Bihar positive relation was found between yield and rainfall over the 40 year period. In Assam, Bangladesh and WB, the correlation coefficient was not constant, and the fluctuations were much larger than UP and Bihar. In Assam, the correlation coefficient was negative until 1975, but after that it turned positive, which means that the drought effect became more prominent than the flood effect. The relation between rice production and Southwest Monsoon Rainfall (SMR) is very low in Bangladesh and Assam, and this is because the correlation coefficient changed adversely from positive to negative and vice versa over the 40 year period.

In India the kharif rice harvest was found lower when total June-September rainfall was less than the long term average normal (Kumar et al., 2004) and such results were in accordance with those of Webster et al., (1998) and Selvaraju (2003). Weather-rice yield relationship for India stated that increased weather extremes and lower rainfall along with other weather parameters are resulting in a decrease of rice yield (Krishnamurthy et al., 2009 and Lal et al., 1998). Low precipitation coupled with high temperature adversely affects the yield of cereals (Bhandari, 2013) and the grain yield decreased as the amount of water applied decreased (Islam et al., 1997). Variability in rainfall affects the stand establishment and growth duration of the crop (Kamalam et al., 1988). Samui (1999) made a study of growth and yield of one high yielding and four traditional photosensitive rice cultivars grown during the kharif season under rainfed conditions at four sites of India with different rainfall and temperatures. The cultivar technique was used to examine the influence of meteorological parameters on yield of rice. His results reported that, the maximum rice yield was observed when average rainfall ranged between 100-115 cm. Auffhammer et al., (2011) opined that monsoon rainfall is not the only weather variable affecting the kharif rice yield in India. Their statistical analysis of state-level Indian data confirms that drought and extreme rainfall negatively affected rice yield in predominantly rainfed areas during 1966-2002, with drought having a much greater impact than extreme rainfall. Results from the study suggest that total JuneSeptember rainfall is very crucial for determining the yield of the crop. Statistical results obtained from the experiment clearly indicate that this variable (i.e., total rainfall during June to September) is significantly correlated with rice yield and that it can be used to generate a simple drought indicator that is also significantly correlated with yield. Moreover, simulation results indicated that changes in total June-September rainfall and drought frequency had about equal impacts on rice yield during 1966-2002. Increase in rice yield owing to improvements in farming technology have been partially offset by the observed changes in weather over the period 1966-2002 (Auffhammer et al., 2012). On the contrary, for some cultivars such as Jaya, yield decreased with increase in total rainfall during planting to maturity from 900 to 1100 mm (Samui, 1998). Results of Narayanan 
(2004) revealed that, total rainfall during nursery stage was negatively correlated with grain yield in non-significant manner but with straw yield it was significant and positively correlated. During vegetative stage it was non-significant with grain yield, whereas, it showed a significant negative correlation with straw yield. Water deficit during the vegetative stage reduces the plant height, tiller number and leaf area but the crop can recover without much loss in yield if water is available before flowering (Narayanan, 2004). The accumulated rainfall during the tillering phase of the crop growth over and above the normal requirement had significant adverse effect on the straw yield. Rice grain yield was found negatively correlated with rainfall during vegetative stage and number of rainy days during reproductive stage (Sandhu et al., 2013).

Dry weather with reduced number of rainy days is beneficial for the rice crop during the ripening phase which ensures proper grain development and drying. Increase in the number of rainy days may result in higher rainfall which may cause lodging of the crops along with decaying of grains in standing water resulting in a reduced yield (Islam et al., 2017). Flooding caused by high rainfall affects rice crops at any stage of growth although submergence intolerance at the vegetative stage is the most common problem (Mackill et al., 2010).

Production and productivity of rice in terms of its yield, grain weight and number of grains per unit area vary in response to agrometeorological parameters that accelerate the processes of plant growth and development. By exploring the rice-weather associations, it can be encapsulated that, optimum amount of well distributed rainfall during the vegetative and reproductive phase of the crop coupled with reduced aberrations in temperature might probably the main factors dictating rice yield.

\section{References}

Aberra, K. 2011. The impact of climate variability on crop production in Ethiopia: Which crop is more vulnerable to rainfall variability. $9^{\text {th }}$ International Conference of EEA/EEPRY Addis Ababa, Ethiopia.

Adams, R. M., Chen, C. C., McCarl, B. A. and Schimmelpfenning, D. E. 2000. Climate variability and climate change: Implications for agriculture in the long term economics of climate change. $A d v$. Econ. Env. Res. 3:53-60

Agarwal, R., Jain, R. C. and Jha, M. P. 1984. Forecasting yield of rice based on weather parameters (Raipur District). IASRI, ICAR, Library Avenue, New Delhi-12.

Agarwal, R., Jain, R. C., Jha, M. P. and Singh, D. 1979. Joint effects of weather variables on rice yield. Mausam. 34(2), 189-194.

Asada, H. and Matsumoto, J. 2009. Effects of rainfall variation on rice production in the Ganges-Brahmaputra Basin. Clim. Res. 38: 249-260.

Auffhammer, M., Ramanathan, V. and Vincent, J. R. 2012. Climate change, the monsoon, and rice yield in India. Clim. Chang. 111(2): 411-424.

Auffhammer, M., Ramanathan, V. and Vincent, J. R. 2006. Integrated model shows that atmospheric brown clouds and greenhouse gases have reduced rice harvests in India. Proceedings of the National Academy of Sciences. 103(52): 19668-19672.

Auffhammer, M., Ramanathan, V. and Vincent, J. R. 2011. Climate change, the monsoon, and rice yield in India. Clim. Chang. 111: 411-424.

Barnabas, B., Jager, K. and Feher, A. 2008. The effect of drought and heat stress on reproductive processes in cereals. $\mathrm{Pl}$. Cell Environ. 31: 11-38. 
Bhandari, G. 2013. Effect of precipitation and temperature variation on the yield of major cereals in Dadeldhura district of far western development region, Nepal. Int. J. of Plant, Animal Environ. Studies. 3(1).

Bhargava, S. 1974. Influence of rainfall on yield of paddy (Raipur District). Ind. J. Agric. Sci. 50(9): 680-684.

Chaudhary, J. L. 1998. Modeling rice yield with monsoon rainfall in Bastar district of Chhattisgarh region- a case study. Adv. Plant Sci. 11(1): 129-135.

Chen, C. C., McCarl, B. A. and Schimmelfennig, D. E. 2000. Yield Variability as Influenced by Climate: A Statistical Investigation. A Research Contribution to the National Assessment of Climate Change. Agricultural Focus Group, US Department of Agriculture.

Chen, S., Chen, X. and Xu, J. 2014. The economic impact of weather variability on China's rice sector. Environment for Development Centres, Swedish International Development Cooperation Agency (Sida).

Edeh, H. O., Eboh, E. C. and Mbam, B. N. 2011. Analysis of environmental risk factors affecting rice farming in Ebony State, Southeastern Nigeria. World J. Agril. Sci. 7(1): 100-103.

Ekanayake, I. J., Datta, D. S. K., Steponkus, P. L. 1993. Effect of water deficit stress on diffusive resistance, transpiration and spikelet desiccation of rice (Oryza sativa). Annals of Botany. 72(1): 73-80.

Girish R. S., and Hittalmani, K. L. 2004. Influence of climatological factors on rice under different water management practices. Field Crop Abst. 26: 1664.

Gorski, T. and Gorska, K. 2003. The effects of scale on crop yield variability. Agric. Sys. 78:425-434.

Gorski, T., Demidowicz, G., Deputat, T., Gorska, K., Marcinkowska, I., Spoz-
Pac, W. and Krakowiak, A. 1994. Agrometeorological quantification of agricultural year in Poland. Zeszyty Problemowe Postepon Nauk Rolniczyh. 405: 81-87.

Gupta, V. K., Agarwal, K. K., Upadhayay, A. P. and Shanker, U. 2000. Effect of rainfall, number of rainy days and length of rainy season on productivity of rice (Oryza sativa L.). J. Agrometeorol. 2(1): 61-64.

Heinemann, A. B. and Stone, L. F. 2009. Efeito da deficiencia hídrica no desenvolvimento e rendimento de quatro cultivares de arroz de terras altas. Pesquisa Agropecuaria Tropical. 39: 134- 139.

Ho, C. H., Yang, C. M., Hsiao, C. L. and Lai, M. H. 2013. Changes of climatic variables during grain filling stage affect yield and quality of rice cultivars bred from different regions in Taiwan. J. Taiwan Agric. Res. 62(4): 321-339.

Hoa, T. V. and Singh, J. B. 1993. Pre-harvest forecasting of rice yield at Pantnagar on the basis of weather parameters. $J$. Indian Society of Agril. Stat. 45 (1): 102.

IPCC. 2013. Climate Change 2013: The Physical Science Basis - Anthropogenic and Natural Radiative Forcing Supplementary Material. Cambridge University Press, Cambridge, United Kingdom and New York, NY, USA.

Islam, A. N., Khanikar, P.G., Deka, R. L. and Goswami, B. 2017. Impact of weather parameters on winter rice productivity in the upper Brahmaputra valley zone of Assam. J. Agrometeorol. 19:75-79

Islam, M. S., Haque, M. Z., Jabber, M. A., Basak, A. K. and Paul, N. K. 1997. Effect of simulated rainfall at reproductive to ripening stages on the growth and yield of transplant Aman Rice. Ann. Bangladesh Agric. 7(2): 105110. 
Jagadish, S. V. K., Sumfleth, K., Howell, G., Redona, E., Wassmann, R. and Heuer, S. 2007. Temperature effects on rice: significance and possible adaptation. Retrieved from: http://climaadapt.org/ wpcontent/uploads/ 2011/12/ Jagadish 2007RiceImpact.pdf.

Kamalam, J., Menon P. K. G. and Koruth, A. 1988. Influence of weather parameters on wetland rice yields in Kerala. Oryza. 25: 365-368.

Karim, M. A., Fracheboud, Y., and Stamp, P. 1997. Heat tolerance of maize with reference of some physiological characteristics. Ann. Bangladesh Agri. 7: 27-33.

Kim, J., Shon, J., Lee, C. K., Yang, W., Yoon, Y., Yang, W. H., Kim, Y. G. and Lee, B. W. 2011. Relation between grain filling duration and leaf senescence of temperature rice under high temperature. Field Crops Res. 122: $207-$ 213.

Kobata, T., and Uemuki, N. 2004. High temperatures during the grain-filling period do not reduce the potential grain dry matter increase of rice. Agron. J. 96: 406-414.

Krishnamurthy, C. K. B., Lall, U. and Kwon, H. H. 2009. Changing frequency and intensity of rainfall extremes over India from 1951 to 2003. J. of Clim. 22(18): 4737-4746.

Kumar, K. K., Rupa, K. K., Ashrit, R. G., Deshpande, N. R. and Hansen, J. W. (2004). Climate impacts on Indian agriculture. Int. J. Climatol. 24: 13751393.

Kumari, P. B., Londhe, A. L., Daniel, S. and Jadhav, D. B. 2007. Observational evidence of solar dimming: Offsetting surface warming over India. Geophysical Res. Letters. 34(21).

Lal, M., Singh, K. K., Rathore, L. S., Srinivasan, G. and Saseendran, S. A. 1998.Vulnerability of rice and wheat yields in NW India to future changes in climate. Agril.and Forest Meteorol. 89(2): 101-114.

Liu, J. X., Liao, D. Q., Oane, R., Estenor, L., Yang, X. E., Li, Z. C. and Bennett, J. 2006. Genetic variation in the sensitivity of anther dehiscence to drought stress in Rice. Field Crops Res. 97: 87-100.

Mackill, D. J., Ismail, A. M., Kumar, A., and Gregorio, G. B. 2010. The role of stress-tolerant varieties for adapting to climate change. Based on a paper from the CURE Workshop on Climate Change, Siem Reap, Cambodia.

Mall, R. K. and Singh, K. K. 2000. Climatic variability and wheat yield progress in Punjab using CERES-wheat and WTGROWS models. Vayu Mandal. 30(3-4): 35-40.

Narayanan, A. L. 2004. Relative influence of weather parameters on rice hybrid and variety and validation of CERES-Rice model for staggered weeks of transplanting. Ph.D. Thesis. Tamil Nadu Agricultural University, Coimbatore.

Ogbuene, E. B. 2010. Impact of meteorological parameters on rice yield: an approach for environmental resource sustainability in Ebonyi rice farmland, Nigeria. J. Environ. Issues Agri. Dev. Countries. 2: 2-3.

Oh-e, I., Saitoh, K. and Kuroda, T. 2007. Effects of high temperature on growth, yield and dry-matter production of rice grown in the paddy field. Plant Prod. Sci. 10: 412-422.

Orcutt, D. M. and Nelson, E. T. 2000. The physiology of plants under stress, soil and biotic factors. John Wiley and Sons, Inc., $6053^{\text {rd }}$ Avenue, New York, NY, pp. 683.

Pathak, H., Ladha, J. K., Aggarwal, P. K., Peng, S., Das, S., Singh, Y., Singh, B., Kamra, S., Mishra, B., Sastri, A., Aggarwal, H. P. and Das, D. K. 2003. 
Trends of climatic potential and onfarm yields of rice and wheat in the Indo-Gangetic Plains. Field Crops Res. 80: 223-234.

Pattanayak, A. and Kumar, K. S. K. 2013. Weather Sensitivity of Rice Yield: Evidence from India. Working paper. Madras School of Economics, Chennai, India.

Peng, S., Huang, J. E., Laza, R. C., Visperas, R. M., Zhong, X., Centeno, G. S. and Cassman, K. G. 2004. Rice yields decline with higher night temperature from global warming. Proc. Nat. Acad. Sci. U.S.A. 101: 9971-9975.

Praba, M. L., Vanangamudi, M., and Thandapani, V. 2004. Effect of low light on yield and physiological attributes of rice. Crop Manag. Physiol. 29(2): 71-73.

Prabhjyot, K. and Hundal, S. S. 2009. Effect of inter and intra seasonal variability in meteorological parameters on wheat yields in Punjab. J. Agrometeorol. 11(2): 117-124.

Ramanathan, V. C., Crutzen, P. J., Kiehl, J. T. and Rosenfeld, D. 2001. Aerosols, climate, and the hydrological cycle. Sci. 294 (5549): 2119-2124.

Ramanathan, V., Chung, C., Kim, D., Bettge, T, Buja, L., Kiehl, J. T. and Wild, M. 2005. Atmospheric brown clouds: impacts on South Asian climate and hydrological cycle. Proceedings of the national academy of sciences of the United States of America. 102(15): 5326-5333.

Rani B. A., and Maragatham, N. 2013. Effect of Elevated Temperature on Rice Phenology and Yield. Ind. J. of Sci. and Technol. 6(8).

Reddy, K. S. and Reddy, B. B. 1992. Correlation coefficients for crop weather relationships in rice. J. Res. APAU. 20(1-2): 85-87.
Samui, R. P. 1999. A note on the weather and rice yield relationship at some stations in India. Earth Planet Sci. 108(4): 309371.

Samui, R. P., Chawdhary, A. and Vaidya, N. G. 1998. Influence of weather on yield of rice. J. of Tropical Agri. 36 (1-2): 73 75.

Sandhu, S. S., Kaur, P., Gill, K. K. and Bala, A. 2013. Effect of inter and intra seasonal variability in meteorological parameters on rice productivity in central Punjab. J. Agrometeorol. 15(2): 147-151.

Selvaraju, R. 2003. Impact of El Ninosouthern oscillation on Indian foodgrain production. Int. J. Climatol. 23: 187206.

Shahid, M. Q., Li, Y. J., Saleem, M. F., Naeem, M., Wei, C. M. and Liu, X. D. 2013. Yield and yield components in autotetraploid and diploid rice genotypes (indica and japonica) sown in early and late seasons. Aust. J. Crop Sci. 7(5): 632-641.

Shakoor, U., Saboor, A., Baig, I., Afzal, A. and Rahman, A. 2015. Climate variability impacts on rice crop production in Pakistan. Pak. J. Agric. Res. 28: 1 .

Sheehy, J. E., Elmido, A., Centeno, G. and Pablico, P. 2005. Searching for new plant for climate change. $J$. Agrometeorol. 60: 463-468.

Silva, S. C. and Assad, E. D. 2001. Zoneamento de riscosclimáticospara o arroz de sequeironosestados de Goiás, MatoGrosso, MatoGrosso do Sul, Minas Gerais, Tocantins e Bahia. Revista Brasileira de Agrometeorologia. 9: 536- 543.

Singh, S. 2001. Growth, yield and biochemical response of rice genotype to low light and high temperaturehumidity stress. Oryza. 37(1): 35-38. 
Sridevi, V. and Chellamuthu, V. 2015. Impact of weather on rice - A review. Int. J. Appl. Res., 1 (9): 825-831.

Upadhyay, J. 2012. Climate Change and its Impact on rice productivity in Assam. Social Science Research Network. Retrieved from http://ssrn.com/abstract $=2172183$ or http://dx.doi.org/ $10.2139 /$ ssrn. 2172183

Wahid, A., Gelani, S., Ashraf, M. and Foolad, M. R. 2007. Heat tolerance in plants: An overview. Environ. Exp. Bot. 61: 199-223.

Wassmann, R. and Dobermann, A. 2007. Climate change adaptation through rice production in regions with high poverty levels. J. Semi-Arid Tropical Agril. Res., 4(1).

Wassmann, R., Jagadish, S. V. K., Heuer, S., Ismail, A., Redona, E., Serraj, R., Singh, R. K., Howell, G., Pathak, H. and Sumfleth, K. 2009b. Climate change affecting rice production: the physiological and agronomic basis for possible adaptation strategies. $A d v$. Agron., 101: 59-122.

Wassmann, R., Jagadish, S. V. K., Sumfleth, K., Pathak, H., Howell, G., Ismail, A., Serraj, R., Redona, E., Singh, R. K. and Heuer, S. 2009a. Regional vulnerability of climate change impacts on Asian rice production and scope for adaptation. Adv. Agron., 102: 91-133.

Webster, P. J., Magana, V. O., Palmer, T. N., Shukla, J., Tomas, R. A., Yanai, M. and
Yasuna, T. 1998. Monsoons: processes, predictability, and the prospects for prediction. J. Geophys Res., 103: 14451-14510.

Welch, J. R., Vincent, J. R., Auffhammer, M., Moya, P. F., Dobermann, A. and Dawe, D. 2010. Rice yields in tropical/subtropical Asia exhibit large but opposing sensitivities to minimum and maximum temperatures. Proc. Natl. Acad. Sci. U.S.A. 107: 14562.

Yamakawa, H. T., Hirose, T., Kuroda, M. and Yamaguchi, T. 2007. Comprehensive expression profiling of rice grain fillingrelated genes under high temperature using DNA micro array. Plant Physiol., 144: 258-277.

Yoshida S. 1981. Fundamentals of rice crop science, IRRI, Philippines.

Yoshida, S. 1973. Effects of temperature on growth of rice plant (Oryza sativa L.) in a controlled environment. Soil Sci. Plant Nutr., 19: 299-310.

Yoshida, S. and Parao, F. T. 1976. Climatic influence on yield and yield components of lowland rice in the tropics. Climate and Rice. International Rice Research Institute, Los Banos, Philippines. pp. 471-494.

Zhu, C., Xiao, Y., Wang, C., Jiang, L., Zhai, H. and Wan, J. 2005. Mapping QTL for heat-tolerance at grain filling stage in rice. Rice Sci., 12: 33-38.

\section{How to cite this article:}

Athar Nishat Islam, Punya Gogoi Khanikar, Rajib Lochan Deka, Bikashjyoti Gharphalia, Pranjal Dutta and Kuldip Medhi. 2018. Weather Manifested Rice Cultivation - A Review. Int.J.Curr.Microbiol.App.Sci. 7(10): 63-73. doi: https://doi.org/10.20546/ijcmas.2018.710.008 